\title{
Connecting India: the rise of standards in service offshoring
}

\author{
Jean-Christophe Graz* and Nafi Niang \\ Institut d'Etude Politiques et Internationales, Centre de recherches interdisciplinaires sur \\ l'international, Université de Lausanne, Lausanne 1015, Switzerland
}

(Received 5 October 2010; final version received 23 March 2011)

\begin{abstract}
This paper explores the role of international standards in the globalisation of the service economy. Various strands of economic analyses consider that core attributes of services affect their ability to be reliably delocalised, industrialised, and standardised. In contrast, international political economy (IPE) approaches draw attention to power configurations supporting conflicting use of standards across industries and nations. The paper examines the case of the Indian service industry in business process outsourcing to probe these opposing views. The findings suggest that standards matter in types of services conventionally identified as unlikely to be standardised, and that their use raises little conflict. An IPE perspective on service standardisation highlights, however, the importance of potential power issues likely to be included in more progressive forms of standardisation.
\end{abstract}

Keywords: standardization; customization; international standards; outsourcing

\section{Introduction}

This paper explores how the internationalisation of IT-enabled services and business process outsourcing (BPO) relies on a wide range of standards involving contrasting forms of intermediation. The service sector is at the core of current debates on the transformations of contemporary capitalism towards a more sustainable global order than that which the crisis of financial capitalism has left behind it. The promise of a knowledgebased economy is largely made on the assumption that, as services become intertwined in manufacturing processes on a global scale, expertise and innovation embodied in such high-skilled services will pervade the economy as a whole. As Boden and Miles (2000a, p. 258) point out, 'the service economy is not merely an economy in which service sectors are quantitatively dominant. It is one where "service" is becoming a guiding principle throughout the economy'. It is often unclear, however, to what extent this convergence thesis fits with theoretical and empirical evidence.

Conventional understandings of these recent developments tend to conflate the concepts of globalisation, harmonisation, and standardisation. Building upon the so-called Stanford school's approach to world society, analyses emphasise how standards are related to the diffusion of a world culture reinforcing Western rationalisation (Loya \& Boli, 1999). In the same line of reasoning, Brunsson (2000, p. 107) reminds us that international standards remain 'disembedded from their country-specific and time-specific contexts (...) distanced and disconnected from time and space and rendered generalizable'. For more than two decades, however, studies in management have debated whether

*Corresponding author. Email: jean-christophe.graz@unil.ch 
globalisation pressures in the domain of services will lead to further standardisation and industrialisation or, on the contrary, to renewed customisation. Standards are conventionally valued as market tools to enhance service productivity, reliability, and competitiveness, ensuring that they are properly delivered to the customer according to predefined requirements (Blind, 2004; Johnson \& Nilsson, 2003; Zeithaml, Parasuraman, \& Berry, 1990). For their part, studies emphasising the advantage of a personalised customisation consider that the distinct logic of service provision in high value-added relational activities supposes that the only viable management and marketing strategy for firms is to maintain personal contacts with the customers (Grönroos, 1990; Normann, 1991). As Timmermans and Epstein (2010, p. 74) have recently pointed out from a broader sociological vantage point, one should not overstate the grand narratives of homogenisation and standardisation, which not only fail to 'account for local interpretations, but also may fail to engage with significant shifts away from, or challenges to, economic, social, or cultural homogeneity'.

Macroeconomic institutionalist approaches have highlighted that the puzzle of service standardisation should be analysed beyond marketing and management choices. Sourcing services rely on ICT infrastructure, foreign trade, movements of workers and consumers, an enabling regulatory and institutional environment, as well as some degree of standardisation. Yet, stereotyped behaviours induced by standardised management processes can reinforce a dualist and unbalanced growth regime, leading to major difficulties brought on by sweeping divergence in productivity. Moreover, the choice of service customisation should be situated within the broader picture of progressive alternatives addressing social and gender inequalities, as well as the societal impacts of those standards (Du Tertre, 1999; Gadrey \& Gallouj, 1998; Petit, 2007). Many accounts tend to confine such alternatives to distinct types of services: unmistakably, relational and intangible services are seen as better candidates for progressive customisation than logistics, maintenance, and information activities, all of them well placed for additional standardisation. The studies are therefore inclined to hypothesise an industry specificity in service standardisation, which assumes that standards matter more for some services than for others. Finally, while institutionalist studies shed light on the social and political embeddedness of service activities within distinct national varieties of capitalism, they fail to explore how standards can be used as transnational tools. Standardisation is not dependent on national institutional environments, but on the extent to which such informal market tools are recognised on a worldwide basis.

International political economy approaches have provided further insights on how standardisation should be situated within power and exclusion processes on a global scale - a context deeply entrenched in the US-based growth of large private communication and information services (Comor, 1999). By identifying standards as tools that compete conventional rule-making processes, they highlight the power configurations of non-State actors who set and use standards according to conflicting definitions of market requirements. They uncover the range of issues concerned and the transnational scale on which coalitions build the consensus required to adopt international standards (An \& Maskus, 2009; Egan, 2001a; Graz, 2006b; Mattli, 2001; Murphy \& Yates, 2009). Until now this scholarship has largely focused on trade in goods and official standardisation bodies such as the International Organisation for Standardisation (ISO). There is little clear understanding of how the distinct feature of a knowledge-based economy based on intangible and interpersonal services such as education or business services may amend assumptions made from standards in goods. Moreover, the magnitude and impact of technical specifications devised outside official standardisation bodies are often neglected. 
Against this background, one question remains largely unanswered: do standards matter in offshoring services across national institutional environments and independently of the nature of the industry they serve? This paper focuses on the case of the rising Indian service industry in customer centres and BPO to probe the extent to which standards in these activities deviate from conventional accounts focused on national environments and industry specificity, as well as from international political economy studies of product standards that single out conflicting market definitions. Our findings suggest that standards matter even in types of services conventionally identified as least amenable to standardisation and internationalisation, and that standards most widely used little reflect conflicting definitions of market access requirements. The paper provides insights on conceptual and empirical grounds on this strong deviation from existing accounts of service standards in institutional economics and standardisation of goods in international political economy. The second section presents our methodology. The third section provides background on the development of an export-oriented service economy in India. The fourth section examines in more detail the link between services, quality and security uncertainty, and international standards; it outlines the conceptual framework by drawing upon the insights of institutional economics, regulation theory, and international political economy. The fifth section presents findings on the rise and range of standards in the Indian BPO sector. The conclusion completes the argument.

\section{Methodology}

The significance of the case study obviously relies on the importance of India, which accounts for more than half of the global market of outsourced services despite the growing share of competing countries such as the Philippines or Morocco (Nasscom, 2010). It also arises out of a purposeful sampling among different types of services. In qualitative methods, purposeful sampling is a privileged means to identify informationrich cases. As Patton (1990, p. 169) reminds us, 'information-rich cases are those from which one can learn a great deal about issues of central importance to the purpose of the research, thus the term purposeful sampling'. To identify what stands out in current and future standards developments across widely diverse forms of services, a relevant sample of cases is expected to have either high or low values on the main characteristics differentiating the service economy. There is, however, a lack of commonly accepted typology of the service sector in official statistics (international datasets even vary for instance between the UN system and the one used by the IMF), as well as in scholarly literature. In order to reconcile conventional distinctions based on categories such as business/non-business services or services to households/companies with more critical approaches focused on productive configurations between labour, technologies, and organisational mechanisms (Du Tertre, 1999, 2002), four key criteria may be distinguished:

1. Relational intensity: transactions in services, in contrast to goods, imply an effect of the recipient on the provider's behaviour; yet, depending on the sector and the organisational structure chosen to provide the service, the intensity of the relation between the recipient and the provider may vary a great deal, ranging from professional counselling to transport logistics.

2. Immateriality: the types of 'support' targeted by the action of the service differ considerably; they can range from the very material (e.g. objects to be maintained or 
financial assets valorised) to largely immaterial (e.g. individuals to be counselled, coded information processed, or organisations managed).

3. Consumers' implication: despite an ever-increasing complexity of productive configurations involving all sorts of intermediaries and outsourcing processes, services can still be distinguished between business services, whose transactions target the business community, and consumer services, directly implying the consumer as an end-user.

4. Labour intensity: in a context of massive industrialisation in the service economy driven by information and communication technologies, services can involve large amounts of capital (e.g. transport), but can still mostly rely on skilled or unskilled labour (as in consulting or call centres).

Among numerous sub-sectors with varying scores from criteria to criteria, customer centres and BPO in the Indian service industry match such a purposeful sampling. The case scores relatively high value scores on all four characteristics, depending on the segments of the value chain in which such services are provided. It should be noted, however, that customer centres and business process outsourcing include services that span B2C and $\mathrm{B} 2 \mathrm{~B}$ activities, as well as activities reflecting various degrees of immateriality (from rudimentary data processing and hardware maintenance to IT and non-IT knowledge resources and analysis). Our sampling nevertheless exemplifies an industry with potentially high relational intensity, immateriality, end-user orientation (particularly for customer centres) and labour intensity - all characteristics supposedly inducing greater quality uncertainty and lack of reliability. According to the industry specificity thesis, such services are less likely to be internationalised and standardised than others such as transport systems which rely on large infrastructures with a low relational intensity, a greater materiality, a strong business-oriented implication, and capital intensity. Customer centres and BPO in India thus appear to be particularly relevant for examining the assumption that service standardisation is more likely to occur in specific industries and national environments than others.

The dataset presented in this paper dates from before the global crisis hit emerging countries in early 2008. While those data provide evidence of trends following a decade or so of continuous high growth in the industry, they cannot bring additional information to the current debate on the impact of the crisis on the future of service offshoring. The data are drawn from the following sources: first, interviews we conducted with around 30 corporate executives, officials from standardisations bodies, professional associations, union representatives, and academics during a research trip in India (Delhi, Gurgaon, Bangalore) in January-February 2008 (all the interviews were conducted by using open-ended questions). We also collected printed and Internet-published materials from the institutions to which the interviewees belong as well as by other bodies. Moreover, we collected documents published by the specialised press in India and those related to the IT-BPO sector on a worldwide basis by using the database Lexis-Nexis.

\section{BPO services in India}

The Indian service industry ranks first among the growing number of developing countries, having shifted away from primary and manufacturing exports to services. Indian export services are often portrayed as activities situated at the bottom end of a value chain packed with a low-skill workforce working in a highly automated and Taylorised environment reproducing the mass production model (Batt \& Moynihan, 2002). It is true that 
many companies still work in low-end domains, such as those providing uninformed guinea pigs for clinical tests on new pharmaceutical products, basic software programming, or so-called outbound call centres attempting to sell cheap products over the phone. In this view, India is what Taylor and Bain called 'an extreme version of the mass production model' (Taylor \& Bain, 2005, p. 277). Yet over the last few years, a number of companies have scaled up the value chain to provide highly complex services. It appears that export-oriented IT services in India, despite a low ITC penetration rate in the country as a whole, now belong to the top worldwide hierarchy of IT services. Companies deliver products as diverse as data and market research, IT enabling services, back office accounting and pricing, multimodal customer centres, legal analysis, or medical distant support. According to data provided by Nasscom (2010), the leading professional association of industry in India, the country still accounted for more than half of the overall world exports of IT-BPO services in 2010, after a decade of yearly growth rate estimated at around 30\% before the outbreak of the global crisis in 2007-2008. Customer centres, back office tasks in IT industries, and more sophisticated activities known as IT-enabled services (ITeS) and BPO involve large and small Indian companies as well as foreign affiliates of multinational corporations. BPO services belonging to the upper end of the value chain remain the fastest-growing segment of the industry, with export revenues estimated to reach $25 \%$ of the whole industry in the fiscal year 2010 (USD 12.4 billion out of a total of 50.1 billion) (ITeS). A number of Indian companies have become multinational corporations on their own, with affiliates in other Asian countries, Europe, and North and South America. The three largest - Tata Consultancy Services (TCS), Infosys, and Wipro were involved in the industry from the late 1970s and early 1980s.

Studies portraying the success story of the Indian service industry, and its prominence in the global market of outsourced services, have proliferated over the last decade. In Thomas Friedman's best-selling account of the new 'flat world' of the 21 st-century globalisation, the Indian service industry plays a crucial role, which resembles that of a dream business story: 'America and India started dating, and that relationship became a huge flattener, because it demonstrated to so many different businesses that the combination of the PC, the Internet, and fibre-optic cable had created the possibility of a whole new form of collaboration and horizontal value creation: outsourcing' (Friedman, 2006, p. 131). This is what makes India's position among large emerging powers so distinct, in particular as compared to China's strategy based on mass manufacturing. As noted by Harris (2005): 'India's main insertion into the global economy comes from its rapid advance in information technologies and pharmaceutical. It's a high end strategy ... particularly as India became a choice for offshoring IT jobs from the US'. Yet, it should be noted that IT-related foreign investments and outsourcing of services were strongly promoted by an enabling State even before the major policy changes marked by the creation (in 1989) of the Software Technology Parks of India (STPI) providing infrastructural support and tax-free status to wholly export-oriented IT firms, the multiplication of Exports Processing Zones in the context of the 1991 regulatory reforms, and the introduction of Free Trade Zones in 1999 (Chakravartty, 2004; Lal, 2001). As Saraswati reminds us in examining the decades preceding the 1990s, the 'ever present and continuing importance of State intervention in the structural transformation of the Indian IT industry' should be placed in a larger historical and political perspective (Saraswati, 2008, p. 1151).

Even if foreign companies such as American Express, GE Capital, and Hewlett Packard played a leading role in the development of the industry in the late 1980s and early 1990s (Arora \& Athereye, 2002), they relied on the excellence of parts of the Indian education system fed by a dense network of Indian Institutes of Technology 
(IITs) and Indian Institutes of Management (IIMs) dating back to the 1950s. While they built up technology transfers and capital contribution, they also succeeded in taking stock of advice provided by local staff. As recalled by Raman Roy, known as the father of the BPO industry in India and currently CEO of a cutting-edge Indian BPO company, the bet was 'to bring the Indian perspective and be confident enough on the greater efficiency of the Indian workforce' (personal communication, Gurgaon, India, 8 February 2008). At the same time, early foreign investors in service offshoring drew heavily on the 1990s managerial culture of reengineering by decomposing and standardising all sorts of business practices (Dossani \& Kenney, 2007, p. 775).

According to The Economist ('Information Technology in India. Gravity's pull', 15 December 2007), rarely has an industry grown so rapidly for so long. As the United States alone accounts for about two-thirds of these revenues, which are particularly exposed to the banking, financial, and insurance industry (nearly $40 \%$ in fiscal year 2006-2007, according to Nasscom (2007)), this path is under heavy pressure in the context of the current global crisis. While in this regard Indian service outsourcing is poised to face - like most other industries - a global slowdown, recovering strategies still rely on factors to be situated beyond microeconomic practices such as strategic managerial choices, improved IT solutions, and increased wage pressures. Moreover, many of those services remain profoundly intangible and interpersonal; they require either a highly skilled workforce or personal contacts in domains that cannot be (fully) substituted for capital (i.e. unable to be fully automated in industrialised or emergent economies). Future developments of the industry will undoubtedly target those activities most likely to be further disaggregated into repeatable and scalable tasks on a reliable basis at the global level. They will also have to address increasing demands for improving the quality of services, within well-defined conformity assessment procedures. These are precisely among the core challenges of standardising service offshoring at the global level.

\section{Service offshoring and standards: a conceptual framework}

The service sector is at the core of changes reinforcing the pivotal role of knowledge, information and communication technology (ICT) as a post-industrial society increasingly substitutes the delivery of services for the production of goods. The ability to develop a global market of services is not only a matter of technology or economic logic. It also supposes an ability to define the gradual decomposition of complex work into simpler work sequences. The more fragmented the nature of the labour and consumption processes, the more requirements to codify them. The literature in marketing and management has discussed at length the so-called standardisation dilemma faced by most service firms (Whitelock \& Pimblett, 1997). On the one hand, the pursuit of productivity gains would lead them to develop economies of scale, mass production, and standardisation (Grönroos, 1990; Levitt, 1976; Normann, 1991; Ritzer, 1993). On the other, the distinct nature of service production requires paying particular attention to customers, which in turn supposes that employees provide as many individually tailored services as possible. This form of personalised customisation differs from more conventional marketing strategies devising easily identifiable products to improve their competitive edge. According to Blind, 'because of the intangible nature of services and the information asymmetries thus caused between management and service provider, the need to introduce quality standards for each stage of the service production is especially high' (Blind, 2004, p. 167). Tether, Hipp, and Miles (2001, p. 1116) emphasise how technical, organisational, and strategic features are closely entangled in assessing whether services are likely to be standardised 
or remain customised. Their study backs up approaches that mix the nature of the technology underpinning the service activity and the nature of the market they serve (e.g. Boden \& Miles, 2000b; Djellal \& Gallouj, 2002). Moreover, it provides additional ground to studies examining how standardisation and customisation logics are increasingly blurred 'to combine the advantages of standardisation (the possibility of increasing productivity) with those of customisation (individual customer satisfaction)' (Sundbo, 2002, p. 104). While the literature emphasises the importance of standards in providing reliability, it never fails to stress that core attributes of services often aim at retaining a critical level of individuation. Notions such as 'modulisation' (Sundbo, 2002) or 'mass customisation' (Pine, 1993) catch this distinction. On the whole, however, these studies lend support to the industry specificity thesis. Despite the emphasis placed on the diversity of service activities found between and within sectors, and on the importance of the size of firms in choices made between standardisation and customisation, the relational and intangible dimension of the service delivered is expected to remain a major hindrance to any standardisation process facilitating the offshoring of services. Moreover, as the prime concern of such studies is to provide more insights on the causal factors behind service innovation, they shed little light on the broader political economy dimension in which such processes take place.

Institutionalist accounts provide further analyses of the social and political aspects of service activities. Following early studies by Baumol (1967), Petit (2007) stresses how the emerging service economy tends to reinforce unbalanced growth patterns, dualism, and stagnancy. Gadrey (2003, p. 76) correlates divergent types of commodified and non-commodified services, high- and low-skilled employment, and varieties of capitalism in terms of social and gendered inequalities within distinct national environments. According to him, a very inegalitarian society (with deep class and gender inequalities) cannot have the same service economy as a more egalitarian one. The former is likely to support service rationalisation based on productivity, standardisation, and economies of scale. The latter, on the contrary, would choose more reflective practices, work routines, and a use of technology supporting labour and gender equality in contrast to conventional labour substitution and unequal division of labour between services delivered by men and women. Du Tertre (1999) makes a similar assumption in analysing productive configurations between labour, technologies, and a wide range of organisational mechanisms. While some types of services can be highly delocalised, industrialised, and standardised, others cannot. In other words, core attributes of services affect their environment. According to du Tertre, quality uncertainties affect both the production process and the competitive environment; they arouse suspicion of the nature and the use of the service provided. A neo-Taylorist standardisation of services is one possible response to the cost/quality conundrum. It favours industrial methods applied to services, stereotyped behaviour, and standardised information denying the specificity of the service relationship. Pre-selection by touchtone telephones and decision trees in offshore contact centres would be examples. Yet a rapid surge of offshoring services going that way is considered to be unlikely since intangible and relational activities are embedded in deeply socialised forms of accessibility with strong territorial and cultural underpinning. Here the industry specificity of intangible and relational services works as a resilient hindrance to standardisation and internationalisation (Du Tertre, 2008). Following the vein of Gadrey, du Tertre identifies a more progressive response within the confines of entrenched national environments. The outcome would be a compromise that includes deontology as a factor, resembling those for regulated professions such as law and medicine, requiring greater involvement of service providers and beneficiaries in defining a common use of services. 
International standards represent important tools in this regard. Yet, to what extent do they respond to quality uncertainty beyond distinct productive configuration (the nature of the industry) and national institutional compromises (varieties of capitalism)? In other words, what is the standardisation potential in the internationalisations of services across distinct national environments and core attributes of the business concerned? To investigate these questions further, one must pay more attention to the range of actors involved in standardisation, the societal scope of issues concerned, and the transnational scale at which coalitions are formed to set and make use of standards. Such issues have been thoroughly explored by international political economy - a field of study closely related to international relations scholarship in which the theoretical debate on globalisation emerged most decisively. In contrast to conventional approaches highlighting the role of states in prevailing world economic order, a number of scholars base their analysis on a comprehensive understanding of political, economic, and social aspects of power and authority in contemporary capitalism (see for instance O'Brien \& Williams, 2004; Palan \& James, 2007; Rupert \& Solomon, 2006). Recent studies have explored the ability of non-State actors to cooperate across borders in order to establish rules and standards of behaviour accepted as legitimate by agents not involved in their definition (Avant, Finnemore, \& Sell, 2010; Grande \& Pauly, 2005; Graz \& Nölke, 2008; Hall \& Biersteker, 2002; Krause Hansen \& Salskov-Iversen, 2008; Sassen, 2006; Strange, 1996). Most of them acknowledge that the logic of action and the potential of change embodied by actors involved in this process are based on consent, implicit or explicit, instead of coercion and forceful compliance. The relationships between states and non-State actors are 'sometimes conflicting but often symbiotic' (Higgott, Underhill, \& Bieler, 1999, p. 6). As Cutler, Haufler, and Porter (1999) argue, 'those subject to the rules and decisions being made by private sector actors must accept them as legitimate, as the representations of experts and those "in authority" (p. 19).

From this perspective, the authority of standards in framing the internationalisation of services entails numerous agents who play, or claim to play, a role not only as new actors, but also on the nature of issues likely to be standardised and on the space in which they exert their power. Regarding the range of actors, service standards reorganise the public and the private spheres through formal and informal regulatory practices that overcome the public/private distinction focused on the nature of the industry. Similarly, they put the State/market distinction into a broader framework to account for the coordination of service firms' behaviour within the national institutions of capitalism. The authority of standards setters blurs the distinction between private and public actors. Moreover, international standards are not always defined on a narrow and flat technical and managerial basis. Even when they are, neo-Taylorist forms of service standardisation span a wide range of management methodologies. In some cases, however, a politicisation process takes place, which prompts the inclusion of a wider range of workers', producers', and consumers' concerns. This could concern an organised group of individuals who initiate a collective action in order to respond to some well-identified problems. While du Tertre situates progressive prospects of standards set by professional deontology in the domestic arena, they can also occur on the international level and override traditional domestic regulatory frameworks. New ICT management standards incorporating diverse strands of privacy, security, and corporate responsibility can be seen as critical cases... Finally, regarding the space in which standards exert authority, coalitions built within standard-setting arenas often reach a transnational scale. Large multinational and technology-driven service firms typically join together for restricting quality management systems to minimum requirements, whereas under-represented workers' 
and consumers' organisations fight to bring to the negotiating table issues including broader societal concerns. Each side reflects its own, conflicting, definitions of market requirements; each tries to exercise its own forms of intermediate authority at a transnational level.

In brief, service standards reorganise the public and the private spheres through formal and informal regulatory practices that deviate from conventional accounts confined to a public/private distinction of the nature of the industry and State/market understanding of coordination issues differentiating national varieties of capitalism. They reflect a form of transnational hybrid authority that blurs the distinction between private and public actors, whose scope can spread all along from physical measures to societal values, and which reinforces the de-territorialisation of informal regulatory practices in contemporary capitalism (Graz, 2006a; 2006b).

Previous international political economy studies on product standards have provided evidence that the growing influence of international standards is promoted by twin conflicting claims. Broader international official standards such as those of the ISO and the growing market of private consortia standards compete with each other in attempts to substitute their power for traditional public law and regulation of utilities. This reflects conflicting perspectives on the definition and the role of standards. Rather than a public/ private or State/market divide, we are looking at a rift between those who favour a commodification of narrow technical standards defined within industrial consortia, and advocates of further socialisation of so-called technical specifications developed by professional associations and standard-setting bodies (Brunsson \& Jacobsson, 2000; Egan, 2001b; Graz, 2004; Mattli, 2001; Murphy \& Yates, 2009; Tamm Hallström, 2004).

In exploring why and how standards matter in offshoring services, the remainder of this paper probes the extent to which the rise of service standards deviates from accounts focused on national institutional environments and industry specificities, as well as from international political economy studies of product standards that stress the ongoing political struggles underpinning the competing definitions of market requirements included in international standards. To this end, the next section presents our findings on the case of international standards used in the Indian BPO sector.

\section{The rise and range of standards in the Indian BPO sector}

In India, as elsewhere, services provided by customer relations centres vary widely, whether their prime target is a mass market and the general public or higher valueadded services performing distinct business-to-business tasks on a contract basis. As mass market call centres handle a large proportion of all customer-company interactions, the level of satisfaction with the services they deliver strongly influences the revenues of such companies. As KiJu, JaeJon and SoonHu (2008, p. 269) argue, 'to provide a high quality of service and to achieve customer satisfaction, call centers are being managed and monitored through a number of key performance indicators (KPIs)'. Compared to outbound call centres targeting a mass market, the higher grade inbound call centres responding to specialised demands from customers and business partners make greater use of sophisticated customer relationship technologies. This phenomenon is likely to be reinforced by the recent growth of a large range of complex ITeS-BPO services. As emphasised in a business report on the international perspectives of the industry, 'levels of standardization and the quality of jobs are typically much lower in mass market centers than in business-to-business centers' (Holtgrewe, Holman, \& Batt, 2007, p. 7). 
Quality requirements in mass market centres typically hinge on standardised performance metrics such as call handling times, rates of failed calls, and numbers of customers per employee per day.

What standards then are used across the Indian service offshoring industry to disaggregate repeatable and measurable tasks on a reliable basis at the global level? And more precisely, is there a distinct feature in the types of the standards most commonly used according to the nature of the industry and the specific tasks performed by the firms reporting the use of such standards?

Table 1 presents the range and core attributes of quality and security standards most widely used in Indian customer centres and ITeS-BPO companies. While some standards originate from official standardisation bodies such as the International Organisation for Standardisation (ISO) and the International Electrotechnical Commission (IEC), others emanate from bodies whose constituencies are more private-oriented as well as from strictly private companies or consortia. Conventional international quality management standards such as ISO 9000 series, ISO/IEC 20000 (quality of management and delivery of IT services), and ISO/IEC 27001 and 27002 (IT security standards and catalogues of best practices) are common in the industry. Standards developed by the Software Engineering Institute (SEI) located at the Carnegie Mellon University - a private American campus - are widely used as well. The Capability Maturity Model Integration (CMMi) is the latest product of the SEI suite. A remarkable aspect of CMMi standards and other products of the same suite is that the Software Engineering Institute which defines those standards is an official research and development centre of the United States government, under the authority of the Office of the Under-Secretary of Defence for Acquisition, Technology and Logistics. While ISO management standards are official standards, relatively broad, with no detailed implementation guidance against which to assess conformity by third-party certifiers, CMMi is a detailed management model of over 700 pages with quantified capability and maturity targets.

Besides ISO/IEC and SEI standards, service offshoring in India relies on tools specifically dedicated to call centres and customer relation services and on a flurry of management methodologies fiercely competing for the lucrative market of business processes certification. COPC (for customer contact centre operations), eSCM (for quality performance in outsourcing), COBIT (another framework for IT management), Six Sigma (a metrics for targeting defect ratios), and SAS 70 (an auditing standard for service reporting) are the most widely used.

Thus, quality and security standards provide crucial tools without which the offshoring of service activities previously located in developed countries would, for the most part, have been unlikely. Standards contribute to overcoming the conventional resistance to relocation conveyed by such characteristics. As Dossani and Kenney (2007, p. 775) suggest, they helped "business decision makers [to] be persuaded that offshoring was an acceptable strategy or "legitimate" [...] by proving that there were appropriate levels of security and sufficient assurances of business continuity. [...] The point was to create the perception that moving one's service operations to India was not "unusual" or "risky", but rather was part of a normal business model'. BPO pioneers of India as well as the younger generation of quality managers in charge of operations share this view. Raman Roy was associated with the development of the COPC standard for customer centres right from their start. Sudeep Banerjee, President for Enterprise Solutions at Wipro, the third largest Indian IT-ITeS company, equates standards to calling cards: 'Wipro could claim being able to implement all sorts of quality standards at world level, even if those standards were not written by us' (personal communication, Bangalore, 
Table 1. Quality and security standards in Indian service companies

\begin{tabular}{|c|c|c|c|c|c|c|c|c|c|c|c|}
\hline Standard Name & ISO $9000 \mathrm{~s}$ & $\begin{array}{l}\text { ISO } 27001 / 2 \\
\text { ISO } 17799\end{array}$ & $\begin{array}{l}\text { BS } 15000 \\
\text { ISO } 20000\end{array}$ & SW-CMM & PCMM & CMMi & eSCM-SP & COPC 2000 & Six Sigma & COBIT & SAS 70 \\
\hline Scope & $\begin{array}{l}\text { Quality mana- } \\
\text { gement system }\end{array}$ & $\begin{array}{l}\text { Security } \\
\text { management } \\
\text { system }\end{array}$ & $\begin{array}{l}\text { IT service quality } \\
\text { management }\end{array}$ & $\begin{array}{l}\text { Software } \\
\text { capability maturity } \\
\text { model. } \\
\text { Management } \\
\text { technique }\end{array}$ & $\begin{array}{l}\text { People capability } \\
\text { maturity model. } \\
\text { Software-focused } \\
\text { on workforce } \\
\text { developments }\end{array}$ & $\begin{array}{l}\text { Capability } \\
\text { maturity model } \\
\text { integration. } \\
\text { Software } \\
\text { management } \\
\text { technique. } \\
\text { Replaces SW- } \\
\text { CMM }\end{array}$ & $\begin{array}{l}\text { eSourcing } \\
\text { capability model } \\
\text { for service } \\
\text { providers }\end{array}$ & $\begin{array}{l}\text { Performance } \\
\text { management } \\
\text { framework for } \\
\text { customer service } \\
\text { providers }\end{array}$ & $\begin{array}{l}\text { Management } \\
\text { methodology } \\
\text { initially based on } \\
\text { metrics targetting } \\
\text { defects in IT } \\
\text { manufacturing }\end{array}$ & $\begin{array}{l}\text { Control } \\
\text { objectives for } \\
\text { information and } \\
\text { related } \\
\text { technology }\end{array}$ & $\begin{array}{l}\text { Statement on } \\
\text { auditing } \\
\text { standards - } \\
\text { service } \\
\text { organisations }\end{array}$ \\
\hline Funding & $\begin{array}{l}\text { Public }+ \\
\text { Private }\end{array}$ & Public + Private & Public + Private & Private + Public & Private + Public & Private + Public & Private & Private & Private & Private & Private \\
\hline Standardisation body & BSI $->$ ISO & BSI -> ISO & BSI $->$ ISO & $\begin{array}{l}\text { Software } \\
\text { Engineering } \\
\text { Institute }\end{array}$ & $\begin{array}{l}\text { Software } \\
\text { Engineering } \\
\text { Institute }\end{array}$ & $\begin{array}{l}\text { Software } \\
\text { Engineering } \\
\text { Institute }\end{array}$ & $\begin{array}{l}\text { IT Services } \\
\text { Qualification } \\
\text { Center }\end{array}$ & $\begin{array}{l}\text { Customer } \\
\text { Operation } \\
\text { Performance } \\
\text { Center }\end{array}$ & $\begin{array}{l}\text { Motorola coporate } \\
\text { university }\end{array}$ & $\begin{array}{l}\text { IT governance } \\
\text { Institute (ITGI) }\end{array}$ & $\begin{array}{l}\text { American } \\
\text { Institute of } \\
\text { Certified Public } \\
\text { Accountants } \\
\text { (AICPA) }\end{array}$ \\
\hline $\begin{array}{l}\text { Umbrella } \\
\text { organisation } \\
\text { or company }\end{array}$ & ISO & ISO & ISO & $\begin{array}{l}\text { Carnegie Mellon } \\
\text { University and US } \\
\text { Department of } \\
\text { Defense }\end{array}$ & $\begin{array}{l}\text { Carnegie Mellon } \\
\text { University and US } \\
\text { Department of } \\
\text { Defense }\end{array}$ & $\begin{array}{l}\text { Carnegie Mellon } \\
\text { University and US } \\
\text { Department of } \\
\text { Defense }\end{array}$ & $\begin{array}{l}\text { Carnegie Mellon } \\
\text { University }\end{array}$ & Private company & Motorola & $\begin{array}{l}\text { Information } \\
\text { Systems Audit } \\
\text { and Control } \\
\text { Association } \\
\text { (ISAC) }\end{array}$ & $\begin{array}{l}\text { American } \\
\text { Institute of } \\
\text { Certified Public } \\
\text { Accountants } \\
\text { (AICPA) }\end{array}$ \\
\hline Release date & $\begin{array}{l}\text { 1994: ISO } \\
\text { 9000, 2000: } \\
\text { ISO 9001:2000 }\end{array}$ & $\begin{array}{l}\text { 2000: ISO 17799, } \\
\text { (ISO 27002 since } \\
\text { 2007), 2005: ISO } \\
27001\end{array}$ & 2005 & $\begin{array}{l}\text { 1990: Version 1, } \\
\text { 2003: Suppressed }\end{array}$ & $\begin{array}{l}\text { 1995: Version 1, } \\
\text { 2001: Version } 2\end{array}$ & $\begin{array}{l}\text { 2000: Version } 1.0 \\
\text { 2002: Version } 1.1 \text {, } \\
\text { 2006: Version } 1.2\end{array}$ & 2001 & 1995 & $\begin{array}{l}\text { Started in early } \\
1980 \text { s }\end{array}$ & $\begin{array}{l}\text { 1996: COBIT 1, } \\
\text { 2005: COBIT } 4\end{array}$ & 1993 \\
\hline Geographic origin & UK $->$ Global & UK $->$ Global & UK $->$ Global & USA & USA & USA & USA & USA & USA & USA & USA \\
\hline
\end{tabular}

Source: Nasscom Strategic review 2007, interviews and compilations by the authors. 
12 February 2008). Satya Gopal Kallluri, Vice President for customer satisfaction and performance management at 24/7 Customer in Bangalore, explained to us that '24/7 started its operation by getting certification in COPC, ISO 9000, ISO 27001 (...) credibility was gained through certification' (personal communication, Bangalore, 13 February 2008). An operational manager for an Indian call centre responding to Orange customers in the UK furthermore explained to us that 'standards are important because they allow us to promise to our customers high efficiency in terms of sales and measure customer satisfaction in different ways' (Operational Manager, personal communication, Gurgaon, India, 6 February 2008). It is not surprising, then, that the Indian IT and BPO industry is notoriously known for including the largest number of quality certifications achieved by any single country: 'over 440 Indian companies had acquired quality certifications with 90 companies certifies at SEI CMM level 5 - higher than any other country in the world' (Nasscom, 2007, p. 99).

Table 2 presents in more detail which companies use which quality and security standards. The dataset includes all top 15 third party Indian BPO players (as of 2006), most top 15 IT software \& service exports companies of India (as of 2006; companies not registered in India such as Accenture or Microsoft excluded), and a sample of top and smaller call centres, customer relations companies, and back office providers. The table provides evidence of the range of standards used in the desegregation process required for outsourcing the provision of distinct services. All reflect a form of neo-Taylorisation in service outsourcing. ISO 9001, 20000, and 27001/2 are used as incentives for stereotyped behaviour and information circulation denying the specificity of a given relational intensity in the service provided. Moreover, the table suggests that narrow performance standards and technical specifications of the industry will be privileged by companies at the lower end of the value chain, mostly involved in basic customer services performed by relatively basic call centres. In contrast, ITeS-BPO services located at a higher end of the value chain will use a much larger range of specifications. The findings of the table are well illustrated by the pride of Sudeep Banerjee, President of Wipro Enterprise Solutions, in claiming that his company is 'ready to adopt all leading standards' (S. Banerjee, personal communication, Bangalore, India, 12 February 2008). Finally, it should be noted that contrary to what would be expected from an international political economy approach stressing conflicting definitions of market requirements along different types of standards, those listed in Table 2 hardly include any form of participatory involvement of either service providers or consumers in defining more socialised and progressive forms of quality and security market requirements.

Fragile initiatives confronting the ascendancy of neo-Taylorist standards have, however, begun at the local level. For instance, ASK-Verite, an Indian not-for-profit organisation, has recently launched a multi-stakeholders dialogue for promoting CSR standards in the IT Electronics Sector (personal communication). Yet, as PD Jose, Professor at the Indian Institute of Management, Bangalore, notes, 'BPO companies are not doing much on the CSR side. Large companies such as Infosys do CSR indeed, but they are not BPO companies as such, only have BPO operations within them' (personal communication, Bangalore, 12 February 2008). While health and safety, energy, environment, and security are central issues in this regard, importance will increasingly be given to problems such as what PD Jose calls 'deskilling' - a process in which the relatively high salaries of the BPO sector work as a disincentive for future training of young graduates. Moreover, a small, but emerging labour movement is trying to organise the BPO and IT workforce at the bottom end. Collective agreements negotiated by Unites Professional, an Indian labour union affiliated to the international umbrella organisation Uni Global, may eventually 
counterbalance the virtually unchecked authority of neo-Taylorist standards in the industry. As Karthik Shekar, General Secretary of Unites Professional, argues, 'managers bring in fancy jargon like CMMi and the like, the middle management, with western culture education, but deeply Indian, ends up totally confused. Call it pcmm-3, but it's just a matter of how people work and the reality on the ground is completely different. [...] There is never the proper time for a real quality check and a lack of trained middle manager to implement it' (K. Shekar, personal communication, Bangalore, India, 13 February 2008). Furthermore, neo-Taylorist standardisation of security requirements has begun to prompt a fierce debate following recent moves by Nasscom, the Indian association of IT professionals, to upgrade security standards in the industry with important consequences on privacy and freedom of movement for the 2 million or so young graduates who make up the bulk of the Indian IT and BPO workforce. Finally, several Indian business executives and standardisation officials are determined to overcome the dominance of USimported Taylorised standards initially conceived for IT manufacturing and basic service outsourcing within the US. The absence of industry-wide standards specifically dedicated to the BPO sector is identified as a typical case in this regard. The situation inherited from the US first-mover statute in outsourcing services is expected to generate difficulties for further consolidation of the sector in India. As Rama Mohan, Head of Business Transformation Group at Infosys BPO, explains, ' (...) for the whole BPO industry (...) all standards adopted are global standards, with no Indian origins (...) there is a need for the Indian model to become a new global model, in which the Indian perspective could be brought' (personal communication, Bangalore, 11 February 2008). Rakesh Verma, additional Director General of the Bureau of Indian Standards, shares this view by emphasising that they 'are bothered that standards are imposed; BPO industries in India should become standards makers and make the standards themselves instead of taking them' (personal communication, New Delhi, 6 February 2008). Similarly, Raman Roy believes that 'India has to take the lead. Carnegie Mellon University set business processes standards for IT, Nasscom should do the same for BPO, with, for instance, Nasscom standards level xyz. That kind of standardization is now critical for our growth rate targets' (personal communication, Gurgaon, India, 8 February 2008). Though fragile, such views and early initiatives on CSR standards provide scattered evidence of a growing dissatisfaction with neo-Taylorised standards and a shared support for standards better involving service providers and consumers alike in defining quality and security requirements with some sort of State or regulatory backing.

\section{Conclusions}

This paper has examined the rising Indian service industry in customer centres and BPO as a case study on the role played by the development of international standards in the muchdebated globalisation of the service economy. Our findings suggest that standards matter even in intangible and relational service outsourcing identified as most unlikely to be standardised. While this finding deviates from studies assuming an industry specificity expected to either support or hinder service standardisation, the nature of the activities still matters in defining the range of standards used, notably according to the position in the value chain of the tasks performed. Even so, it often remains difficult to differentiate between solutions advertised by customer relations and BPO companies and the bulk of actual services they deliver. The high-end BPO solutions standardised by sophisticated management techniques relate to core attributes of intangibility, relational intensity, and skilled labour seen as a major hindrance to standardisation by institutional accounts 
Table 2. Quality and security standards used by top Indian service companies.

\begin{tabular}{|c|c|c|c|c|c|c|}
\hline Compagny name & Specialisation & ISO & Sei $\mathrm{cmm}$ & Sei Pcmm & COPC & Others \\
\hline 24/7 Customer & $\begin{array}{l}\text { Call center/customer } \\
\text { relations/back office }\end{array}$ & ISO 9002, BS 7799 & & & COPC & Six Sigma \\
\hline Aegis BPO Services & ITeS-BPO & & & & & Six Sigma \\
\hline Allsec Tech & $\begin{array}{l}\text { Call center/customer } \\
\text { relations/back office }\end{array}$ & $\begin{array}{l}\text { ISO 9001:2000, ISO 7001:2005, ISO } \\
\text { 27001: } 2005\end{array}$ & & & & SAS 70 \\
\hline Astron & $\begin{array}{l}\text { Call center/customer } \\
\text { relations/back office }\end{array}$ & ISO 9001:2000 & & & & \\
\hline Brigade & ITeS-BPO & ISO 9001:2000, ISO 27001:2005 & & & & Six Sigma \\
\hline CMC Limited & ITeS-BPO & ISO 9001:2000 & $\begin{array}{l}\text { SEI CMM Level 5, } \\
\text { CMMi level } 5\end{array}$ & $\begin{array}{l}\text { PCMM } \\
\text { level } 5\end{array}$ & & Six Sigma, SAS 70 \\
\hline $\begin{array}{l}\text { Cognizant Technology } \\
\text { Solutions }\end{array}$ & ITeS-BPO & ISO 9001:2000, ISO 7799 & $\begin{array}{l}\text { SEI CMM Level 5, } \\
\text { CMMi level } 5\end{array}$ & $\begin{array}{l}\text { PCMM } \\
\text { level } 5\end{array}$ & & eSCM \\
\hline Convergys & $\begin{array}{l}\text { Call center/customer } \\
\text { relations/back office }\end{array}$ & ISO17799:2000, BS 7799 & & & COPC & \\
\hline $\begin{array}{l}\text { Datamatics } \\
\text { Technologies } \\
\text { Limited }\end{array}$ & ITeS-BPO & $\begin{array}{l}\text { ISO } 9001: 2000, \text { ISO } 27001, \text { BS } \\
\quad 7799\end{array}$ & $\begin{array}{l}\text { SEI CMM Level 5, } \\
\text { CMMi level } 5\end{array}$ & $\begin{array}{l}\text { PCMM } \\
\text { level } 5\end{array}$ & & Six Sigma, SAS 70 \\
\hline eFunds Corporation & $\begin{array}{l}\text { Call center/customer } \\
\text { relations/back office }\end{array}$ & & SEI CMM Level 4 & & & Six Sigma \\
\hline EXL Services Holdings & ITeS-BPO & ISO 9001:2000, ISO 27001 & & & $\mathrm{COPC}$ & $\begin{array}{l}\text { OHSAS } 18001 \text { Six } \\
\text { sigma }\end{array}$ \\
\hline Genpact & ITeS-BPO & $\begin{array}{l}\text { ISO 9001:2000, ISO 27001, BS } \\
\text { 15000, BS } 7799\end{array}$ & CMMi Level 5 & & $\mathrm{COPC}$ & \\
\hline GTL & $\begin{array}{l}\text { Call center/customer } \\
\text { relations/back office }\end{array}$ & ISO 9001:2000, ISO 14001: 2004 & CMMi Level 5 & & & SAS 70, Six Sigma \\
\hline HCL Technologies & ITeS-BPO & $\begin{array}{c}\text { ISO 9001:2000, ISO 20000, ISO } \\
\text { 27001, BS 15000, BS } 7799\end{array}$ & CMMi Level 5 & & COPC & Six Sigma \\
\hline Hinduja TMT & $\begin{array}{l}\text { Call center/customer } \\
\text { relations/back office }\end{array}$ & ISO 9001:2000, BS 7799 & SEI CMM Level 4 & & & Six Sigma \\
\hline IBM Daksh & ITeS-BPO & $\begin{array}{c}\text { ISO 9001:2000, ISO 20000, ISO } \\
27001, \mathrm{BS} 15000, \mathrm{BS} 7799\end{array}$ & CMMi level 5 & & $\mathrm{COPC}$ & eSCM \\
\hline
\end{tabular}




(1)

FirstSource (ICICI
OneSOurce)

iFLex solutions

iGATE

Infosys BPO

Integreon

Intelenet Global

Services

MphasiS BBPO

Nipuna services

Patni Computer

Systems Industries

R Systems

Satyam Computer

Services

Sutherland Global

Services

TCS BPO

Trac Mail

TransWorks

Information Services

Vee Insure

Wipro BPO

WNS Global Services
ITeS-BPO

Customer relations/back office/IT

ITeS-BPO

Call center/customer

relations/back office

ITeS-BPO

ITeS-BPO

ITeS-BPO

Call center/customer relations/back office

Call center/customer relations/back offic

ITeS- BPO

Call center/customer relations/back office IteS- BPO

Call center/customer relations/back office

Call center/customer relations/back office

Call center/customer relations/back office

ITeS-BPO

ITeS-BPO
ISO 20000, ISO 27001, BS 7799

ISO 27001, ISO 17799

ISO 9001, BS 7799

ISO 9001:2000, ISO 20000, ISO 27001, BS 15000, BS 7799

ISO 9001:2000, BS 7799

ISO 27001, BS 7799, BS 15000

ISO 9001:2000, ISO 27001:2005

ISO 27001

ISO 9001:2000, ISO 27001:2005

ISO 9001:2000, ISO 27001:2005

ISO 9001, ISO 17799

ISO 9001:2000, ISO 27001:2005

BS 7799, ISO 9001, ISO

27001:2005, ISO 20000:2005

ISO 9001:2000

ISO 9001:2000, BS 7799

ISO 9001:2000, ISO 27001:2005

ISO 9001:2000, ISO 27001

ISO 9001:2000, ISO 27001
COPC Six Sigma

CMMi level 5

SAS 70, CoBIT

CMMi Level 5

SAS 70, CoBIT, Six Sigma

COPC Six Sigma, SAS 70, eSCM, TR 19:2005 Six Sigma

COPC Six Sigma

CMMi Level 5

Six Sigma, SAS 70 Six Sigma, SAS 70

CMMi Level 5

Six Sigma

CMMi Level 5

CMMi level 5

PCMM

Level 5

PCMM

Level 5

CMMi Level 5 PCMM

Level 5

Six Sigma

COPC Six Sigma

CMMi level 5

Sources: Nasscom Strategic review 2007; Securities and Exchange Commission; Companies' websites; Global Services, OSourcebook 2007: A Directory of Global Outsourcing Providers; interviews and compilations by the authors. 
referred to in this paper. Yet services delivered by those same companies are often much more basic, such as data mining, screening, digitising, and processing. Those tasks involve more materiality and less relational intensity and skilled labour; they do not fully embody the core attributes identified by institutional economists to explain why some services are less likely than others to be standardised, industrialised, outsourced, and offshored. Similarly, call centres and customer relations directly imply the consumer as an end-user and our interviews have shown that this does not impede the use of widely recognised international standards to streamline the labour process. Yet, those lower-end services referred to in Table 2 also include back office tasks that do not interact with consumers. Further theoretical, methodological, and empirical research is thus clearly needed to better differentiate services and curb the correlation between standardisation and core attributes of services. This is in line with recent emphasis given to the so-called synthesis approach according to which innovation in service industries can be irrespective of the sector to which a company belongs (Castro, Montoro-Sanchez, \& Ortiz-De-Urbina-Criado, 2011). A good starting point could be to study how our typological criteria (relational intensity, immateriality, consumers' implication, and labour intensity) relate to the innovation-related areas explored by this neo-Schumpeterian scholarship.

Our findings suggest that the standards used in the Indian BPO industry are rarely disputed. Almost all of them rely on neo-Taylorised management techniques. This finding differs from studies in international political economy that emphasise power configurations opposing divergent definitions of market requirements set by standards. It substantiates, however, international political economy scholarship that sheds light on the power of the customer and his ability to impose standards as a counterpart to grant market access. While all our interviewees underlined that gaining market access was a key factor for adopting standards, some of them anticipated a shift from being 'standards takers' towards 'standards makers' in the same way as India is competing with China for a worldwide recognition of their newly acquired status of heavy-weight emerging powers. This chimes well with the point that Murphy and Yates (2009, pp. 76-77) make on the experience of Japanese adoption of ISO 9000 quality standards - a signalling mechanism of modernity and reliability first seen as an offence to their deeper quality culture and higher productivity, then used for launching within the ISO a larger program of quality management from their own perspective. It remains possible that neo-Taylorised standards span such a wide range that they do reflect divergent definitions of market requirements. The relevance of international political economy approaches here lies in their ability to highlight the social impact of standards, their potentially contested power, and the possibility of progressive forms of standardisation more likely to include workers', consumers', and environmental concerns. An international political economy perspective on service standardisation thus provides a valuable tool for strengthening new directions in service innovation and management studies taking the cultural turn seriously (Parellada, Soriano, \& Huarng, 2011). There is also a cultural turn in international political economy (Best \& Paterson, 2010; Jessop \& Oosterlynck, 2008). While Diochon and Anderson (2011) point out that 'value, manifest as culture, shape how things are done', international political economy gives further insight on power configuration beyond the cultural environment of marketing and management choices to analyse broader conflicting definitions of market requirements in the internationalisation of services. 


\section{Acknowledgements}

This article draws on the project 'Standards and International Relations' funded by the Swiss National Science Foundation (SNF) (grant \# PP001-110528). We are grateful to the SNF for its support, to our interviewees for their time, to the anonymous referees and a number of scholars for their comments on earlier versions of the paper, as well as to Liesl Graz for her invaluable help with the language.

\section{References}

An, G., \& Maskus, K. (2009). The impact of alignment with global product standards on exports of firms in developing countries. The World Economy, 32, 552-574.

Arora, A., \& Athereye, S. (2002). The software industry and India's economic development. Information Economics and Policy, 14, 253-273.

Avant, D., Finnemore, M., \& Sell, S. (Eds.). (2010). Who governs the globe. Cambridge: Cambridge University Press.

Batt, R., \& Moynihan, L. (2002). The viability of alternative call centre production models. Human Resource Management Journal, 12, 14-34.

Baumol, W. (1967). Macroeconomics of unbalanced growth: The anatomy of the urban crisis. American Economic Review, 57, 415-426.

Best, J., \& Paterson, M. (Eds.). (2010). Cultural political economy. London: Routledge.

Blind, K. (2004). The economics of standards. Cheltenham: Elgar.

Boden, M., \& Miles, I. (2000a). Conclusions: Beyond the services economy. In M. Boden \& I. Miles (Eds.), Services and the knowledge-based economy (pp. 247-264). London: Continuum.

Boden, M., \& Miles, I. (Eds.). (2000b). Services and the Knowledge-Based Economy. London: Continuum.

Brunsson, N., Jacobsson, B., \& Associates. (2000). A world of standards. Oxford: Oxford University Press.

Castro, L.M., Montoro-Sanchez, A., \& Ortiz-De-Urbina-Criado, M. (2011). Innovation in services industries: Current and future trends. The Service Industries Journal, 31, 7-20.

Chakravartty, P. (2004). Telecom, national development and the Indian State: A postcolonial critique. Media, Culture and society, 26, 227-249.

Comor, E. (1999). Governance and the nation-state in a knowledge-based political economy. In M. Hewson \& T. Sinclair (Eds.), Approaches to global governance theory (pp. 117-134). Albany: SUNY Press.

Cutler, A.C., Haufler, V., \& Porter, T. (Eds.). (1999). Private authority and international affairs. New York: SUNY Press.

Diochon, M., \& Anderson, A.R. (2011). Ambivalence and ambiguity in social enterprise; narratives about values in reconciling purpose and practices. International Entrepreneurship and Management Journal, 7, 93-109.

Djellal, F., \& Gallouj, F. (Eds.). (2002). Nouvelle économie des services et innovation. Paris: L'Harmattan.

Dossani, R., \& Kenney, M. (2007). The next wave of globalization: Relocating service provision to India. World Development, 35, 772-791.

Du Tertre, C. (1999). Intangible and Interpersonal Services: Toward new political economy tools. The French case. Service Industries Journal, 19, 18-34.

Du Tertre, C. (2002). Activités immatérielles et relationnelles: Quels nouveaux enjeux de régulaton pour les secteurs et les territoires? Géographie, Economie, Société, 4, 181-204.

Du Tertre, C. (2008). Globalisation et services: Pour un changement de perspectives. In A. LyonCaen \& Q. Urban (Eds.), Le droit du travail à l'épreuve de la globalisation (pp. 68-81). Paris: Dalloz.

Egan, M. (2001a). Constructing a European market. Standards, regulation, and governance. Oxford: Oxford University Press.

Egan, M. (2001b). Mutual recognition and standard setting: Public and private strategies for governing markets. In M. Pollack \& G. Shaffer (Eds.), Transatlantic governance in the global economy (pp. 179-209). Oxford: Rowman \& Littlefield.

Friedman, T. (2006). The world is flat. London: Penguin.

Gadrey, J. (2003). Socio-économie des services. Paris: La Découverte. 
Gadrey, J., \& Gallouj, F. (1998). The provider-customer interface in business and professional services. Services Indutries Journal, 18, 1-15.

Grande, E., \& Pauly, L. (Eds.). (2005). Complex sovereignty. Reconstituting political authority in the twenty-first century. Toronto: University of Toronto Press.

Graz, J.-C. (2004). Quand les normes font loi: Topologie intégrée et processus différenciés de la normalisation internationale. Etudes Internationales, 25, 233-260.

Graz, J.-C. (2006a). Hybrids and regulation in the global political economy. Competition and Change, 10, 230-245.

Graz, J.-C. (2006b). International standardisation and corporate democracy. In K.-G. Giesen \& K. van der Pijl (Eds.), Global norms in the twenty-first century (pp. 118-133). Cambridge: Cambridge Scholars Press.

Graz, J.-C., \& Nölke, A. (Eds.). (2008). Transnational private governance and its limits. London: Routledge.

Grönroos, C. (1990). Service management and marketing: Managing the moments of truth in service competition. Lanham: Lexington.

Hall, R., \& Biersteker, T. (Eds.). (2002). The emergence of private authority in global governance. Cambridge: Cambridge University Press.

Harris, J. (2005). Emerging third world powers: China, India and Brazil. Race and Class, 46, 7-27.

Higgott, R., Underhill, G., \& Bieler, A. (Eds.). (1999). Non-state actors and authority in the global system. London: Routledge.

Holtgrewe, U., Holman, D., \& Batt, R. (2007). The global call center report: International perspectives on management and employment. Ithaca: Cornell University Press.

Jessop, B., \& Oosterlynck, S. (2008). Cultural political economy: On making the cultural turn without falling into soft economic sociology. Geoforum, 39, 1155-1169.

Johnson, M., \& Nilsson, L. (2003). The importance of reliability and customization from goods to services. The Quality management Journal, 10, 8-19.

KiJu, C., JaeJon, K., \& SoonHu, S. (2008). A study of strategic call centre management: Relationship between key performance indicators and customer satisfaction. European Journal of Social Sciences, 6, 268-276.

Krause Hansen, H., \& Salskov-Iversen, D. (Eds.). (2008). Critical perspectives on private authority and global politics. Houndmills: Palgrave Macmillan.

Lal, K. (2001). Institutional environment and the development of information and communication technology in India. The Information Society, 17, 105-117.

Levitt, T. (1976). The industrialization of services. Harvard Business Review, 54, 63-74.

Loya, T., \& Boli, J. (1999). Standardization in the world polity: Technical rationality over power. In J. Boli \& G. Thomas (Eds.), Constructing world culture (pp. 169-197). Stanford: Stanford University Press.

Mattli, W. (Ed.). (2001). Governance and International Standards Setting. Journal of European Public Policy, 8(Special Issue), 327-492.

Murphy, C., \& Yates, J. (2009). The International Organization for Standardization (ISO). Global governance through voluntary consensus. London: Routledge.

Nasscom. (2007). Strategic review 2007. New Delhi: National Association of the Indian IT-BPO sector.

Nasscom. (2010). Strategic review 2010. Executive summary. New Delhi: National Association of the Indian IT-BPO sector.

Normann, R. (1991). Service management. Chichester: Wiley.

O'Brien, R., \& Williams, M. (2004). Global Political Economy. Evolution and Dynamics. Basingstoke: Palgrave.

Palan, R., \& James, P. (2007). Globalizing economic institutions: A critical introduction. In R. Palan \& P. James (Eds.), Globalization and economy. Vol. 7: Globalizing economic regimes and institutions (pp. 1-14). London: Sage.

Parellada, F.S., Soriano, D.R., \& Huarng, H. (2011). An overview of the service industries' future (priorities: linking past and future). The Service Industries Journal, 31, 1-6.

Patton, M. (1990). Qualitative evaluation and research methods. London: Sage.

Petit, P. (2007). The political economy of services. In J.R. Bryson \& P.W. Daniel (Eds.), The handbook of service industries (pp. 77-97). Cheltenham: Elgar.

Pine, B.J. (1993). Mass customisation. Boston: Harvard Business School Press.

Ritzer, G. (1993). The McDonaldization of society. Newbury Park, CA: Sage. 
Rupert, M., \& Solomon, M.S. (2006). Globalization and international political economy. Lanham: Rowman \& Littlefield.

Saraswati, J. (2008). The Indian IT industry and neoliberalism: The irony of a mythology. Third World Quarterly, 29, 1139-1152.

Sassen, S. (2006). Territory, authority, rights. From medieval to global assemblages. Princeton: Princeton University Press.

Strange, S. (1996). The retreat of the state. The diffusion of power in the world economy. Cambridge: Cambridge University Press.

Sundbo, J. (2002). The service economy: Standardisation or customisation? The Service Industries Journal, 22, 93-116.

Tamm Hallström, K. (2004). Organizing international standardization. ISO and the IASC in quest of authority. Cheltenham: Elgar.

Taylor, P., \& Bain, P. (2005). India calling to the far away towns: The call centre labour process and globalization. Work, Employment and Society, 19, 261-282.

Tether, B.S., Hipp, C., \& Miles, I. (2001). Standardisation and particularisation in services: Evidence from Germany. Research Policy, 30, 1115-1138.

Timmermans, S., \& Epstein, S. (2010). A world of standards but not a standard world: Toward a sociology of standards and standardization. Annual Review of Sociology, 36, 69-89.

Whitelock, J., \& Pimblett, C. (1997). The standardisation debate in international marketing. Journal of Global Marketing, 10, 45-66.

Zeithaml, V.A., Parasuraman, A., \& Berry, L.L. (1990). Delivering service quality. New York: The Free Press. 